\title{
Work Transformations and Their Consequences for the Personal Life of Workers
}

\author{
Renata Tomaszewska-Lipiec \\ Kazimierz Wielki University, Bydgoszcz, Poland
}

\begin{abstract}
The civilisation transformations which occur in the sphere of human work, have a strong influence over their functioning both in the professional and extraprofessional spheres. Scientific analyses, as well as everyday observation, suggest that there are increases in the tension between work and personal life, which results in imbalance and perceiving both the spheres as mutually contradictory, as well as having adverse consequences for workers and their families, organisations, the society, and economics. As regards this occurrence, the aim of the article is to show selected civilizational trends which generate the issues with maintaining work-personal life balance of contemporary humans. The article is of theoretical character and is based on the method of critical literature analysis, as well as on the analysis of formal-legal documents, reports, and statistical sources. The theoretical-case analyses let one formulate a conclusion that the transformation one undergone in the sphere of professional work often bears adverse consequences for the sphere of workers' personal lives and this should be a significant scientific research field.
\end{abstract}

Keywords: civilisational transformation, transformations of work, work, personal life, balance, personal time management

\section{Introduction}

Undoubtedly, people live in the world of constant changes. All the spheres of human lives undergo transformations. Human's work is one of those spheres. Its transformations affect people's functioning in both their professional and personal spheres. This article focuses on the issue of the lack of balance between those two spheres of contemporary human's life. In the context of the so-perceived main issue, the structure of the article is determined by the deliberations on the selected civilizational transformations that occur within the sphere of work and their adverse influence over workers' personal lives.

\section{Work Transformations in Times of Civilizational Changes}

The need to deliberate on people's work seems to be very up-to-date today. On the one hand, for almost 240 years - that is, since Adam Smith's work An Inquiry Into the Nature and Causes of the Wealth of Nations was published - it has been assumed without reservation, that work is the factor of economic growth and the condition for utilising its results; the lack of work is destructive and undermines the basis for the existence of the individual and the society; and unemployment is the basic reason for poverty in the world. On the other

Renata Tomaszewska-Lipiec, Ph.D., assistant professor of pedagogy, Kazimierz Wielki University, Bydgoszcz, Poland.

Correspondence concerning this article should be addressed to Renata Tomaszewska-Lipiec, Department of Labour Pedagogy and Andragogy, The Institute of Pedagogy, Faculty of Pedagogy and Psychology, Kazimierz Wielki University in Bydgoszcz, Chodkiewicza 30, Bydgoszcz 85-064, Poland. 
hand, the opinions have been shaped that the end of work is near. At least, of the work in the traditional understanding of it, that is work based on constant, full-time employment, and precisely-set professional tasks. Work in the information society soon becomes a privilege that is going to be accessible to a small number of highly qualified people. Thus, a question is being asked, if the 21 st century is going to be the age of crisis and the end of work, and at the same time - the beginning of the civilisation of unemployment? It is difficult to address such a question, especially taking the high changeability of the today's world into consideration. Those popular, ominous visions of "the end of work" have both their followers (such as J. Rifkin, Y. Masuda, P. Drucker, R. Dahrendorf, J. Habermas, and others) and opponents. Broader interpretations of this phenomenon were made by, e.g., Rifkin (2001, p. 11), in his book entitled The End of Work: The Decline of the Global Labor Force and the Dawn of the Post-Market Era. As the author writes in it:

The Information Age has arrived. In the years ahead, new and more sophisticated software technologies are going to bring civilization ever closer to a near-workless world. In the agricultural, manufacturing, and service sectors, machines are quickly replacing human labour and promise an economy of near automated production by the mid-decades of the $21 \mathrm{st}$ century. The wholesale substitution of machines for workers is going to force every nation to rethink the role of human beings in the social process. Redefining opportunities and responsibilities for millions of people in a society absent of mass formal employment is likely to be the single most pressing social issue of the coming century. (Rifkin, 2001, p. 11)

In the opinion of the author, limiting the number of workplaces will result in the decrease in significance of work as an autotelic value, which is connected with transforming the world and one's self-realisation. Work is supposed to become a gradually disappearing value. Handy (1998) was of a similar opinion and predicted that in the near future only minority of people in the productive age will be in permanent, full-time employment in the companies managed in the traditional way. The rest will fall into one of the three following groups: (1) task teams - this group is going to be a predominating group of well-paid labour and will comprise people who collaborate, usually in a short period of time, only to perform a given task; (2) seasonal workers or workers who do not work full time - this group will mostly comprise unqualified people or the people of incomplete professional qualifications; and (3) people who work on their own or in family teams (Handy, 1998, pp. 75-97).

When commenting on these signalised predictions, one may only hope that the development of information society does not have to and, most probably, will not directly translate into a significant increase in the unemployment level. This is so, as technological development does not cause insufficiencies in the labour market, but rather changes it structure, thus generates employment in new posts or new kinds of jobs. However, there is no doubt that the sphere of human work has been undergoing and will undergo further great transformations. The process of those transformations may be presented in Figure 1:

\section{Physical work}

(dominates in the hunter-gatherer, hoe-farming, and agricultural economies)

$\Downarrow$

Mechanization $\rightarrow$ Automation $\rightarrow$ Robotization

(dominates in industrial economy)

$\Downarrow$

Informatization and intellectualisation of work

(in developing information economy)

Figure 1. The process of work transformations. Source: author's own findings. 
When discussing the issues of the transformations of human work, one may refer to the most significant civilizational trends, which characterise it in the most comprehensive way at present and in the near future. They are as follows:

(1) Information revolution, which causes rapid increase in effectiveness and complexity of work, greater innovation pace, and significant changes in the standards of living among certain countries, as well as within the countries. Inventions and their even faster introduction into the practice of economic life are the main cause for the increase in productivity, which made people independent of nature, increased people's mobility and communication, and increased the significance of organizations.

(2) Global labour market, the appearance of which caused the increase in the cultural variety of employees and the emergence of competition on a global scale. However, global labour market is characterised by uneven economic development among countries, as well as within those countries. The predominance of developed countries is becoming greater and greater in relation to the developing countries of average income.

(3) Resigning from traditional and agricultural sectors to the advantage of services and the sectors that require high qualifications.

(4) Changes in professions that result from technical development and standardisation of production, which make some professions disappear and some others emerge, and the changes of activities within given professions.

(5) The increase in qualification requirements towards job candidates. It is mostly related to the quality of the product and services being emphasized to a greater extent than ever before. It is also significant to adjust one's qualifications to the changing requirements of particular positions.

(6) Changes in the work sphere are often described as characteristic to the post-Fordism and post-industrial age, and comprise, for example: flexible working time, teamwork, standardisation of the management procedures, being oriented towards clients and consumers, diverse, and even more flexible forms of company organisation, which pose challenges for both employers and employees.

(7) Changes in management, which lead to resigning from workers being under detailed, routine supervision in favour of exploiting their potential. This has many effects, both positive and negative. This is so, as the new character of work needs a more individualised and creative attitude, more relaxed time-space forms, and common access to information and global networks.

Based on the signalised trends, one may assume that the key factor of the 21 st century economy is mostly its changeability - apart from the diverseness of its forms, high level of complexity, a large number of competitive subjects, or treating knowledge as a deciding stimulus of its growth and development. The aforementioned set of factors may be supplemented by the broadly-understood civilisation trends which also have an influence over economic processes:

(1) "Work informatization", which is the most characteristic of the emerging information paradigm. This phenomenon may be best understood in the form of the typology of the work division built around three dimensions, as suggested by Castells (2007, pp. 239-240). The first dimension is related to the actual tasks done in the given work process (value-making dimension). The second one is about the relations between a given organisation and its environment, including other organisations (relation-making dimension). The third dimension takes the relations between the management and workers of the given organisation or network into consideration (decision-making dimension). From the value-making dimension's perspective, in the production process based on information technology (both the production of goods and providing services), one may distinguish the following essential tasks and the corresponding categories of workers: strategic planning and decision making by 
the "commanders"; introducing innovation in products and processes by "researchers"; adapting and targeting innovations by the "designers"; managing the relations among decisions, innovations, projects, and their execution by the "integrators", taking into account the means of achieving the stated goals of the organisation; performing tasks according to one's initiative and understanding by the "operators"; as well as executing ancillary, preprogramed tasks by those, who are called "tools" or "human robots" by Castells (2007, pp. 239-240). This typology may be connected with another one, which refers to the necessity and possibility of combining each task with other workers in real time, either within the same, given organisation, or the whole system of the company. In the light of this relation ability, one may distinguish three basic categories: "networkers" who set up connections on their own initiative; "networked", those are workers who are part of the network but cannot make decisions about their position there; and the "switched-off", represents the people who perform specific tasks which are determined by one-way, non-interactive instructions. When taking the input into the decision-making process into consideration, one may distinguish: "deciders", who make final decisions; "participants" who are involved in decision-making, and the "executants", who only implement those decisions (Castells, 2007).

(2) "Work dematerialization", manifesting itself in the fact that work is less and less often organised to produce goods (although they still constitute a significant part of its final products), in favour of operating with abstractions and ideas. From the point of view of this occurrence, it seems to be the most significant that in the labour market there emerged the category of "knowledge worker", which to a great extent displaces the workers of simple and manual qualifications. Work dematerialization remains closely related to the emergence of new jobs and the change in character of the traditional jobs, to a scale that is larger than ever before. One assesses that during the 10 years of the 1990s of the 20th century, there emerged more new jobs in the world than in the preceding 40 years.

(3) "Work flexibility", related to replacing paid, full time work with the so-called non-standard or flexible employment and work time organisation types. Part-time job, employment for a definite period of time, task-oriented work, and telework or self-employment, has become increasingly popular. The development of work flexibility creates new possibilities concerning how, when, and where it is done. At present, one may wholeheartedly agree that "work is what you do, not where you go to".

(4) "Precarious work", which is the consequence of the flexibility of payments, employment, workplaces, and skills that have been progressing since the 1980s. Precarious work is work that is uncertain, insecure, with no protection, and perspectives, mostly temporary, often poorly paid. Precarious workers (estimated to constitute 1/4 adults in the world) are the workers of the "temporary" status, with no guarantee that in a few years, months, or even weeks they will still be performing the same job; and they also suffer from the lack of basic forms of protection for related to work (Standing, 2011).

(5) The division of the labour market into the "core" and "peripheries", which leads to the emergence of two distinct segments - the basic part, that is the foundation and the marginal part. The "core" consists of the highly qualified workers, employed full-time, and well-paid, who have a stable employment status, take part in trainings, qualify for social benefits, and being promoted, who are absolutely essential from the long-term organisation functioning's point of view. On the contrary, the "peripheries" comprise two groups. The first one also includes the people who are employed full time, but have the skills that are easily obtainable in the labour market. Thus, they have lower chances of pursuing careers and lower job security. The second group consists of the people employed part-time, temporary workers, those who work on the basis of sub-contracts, the self-employed, sometimes called "buffer" workers, who often perform the so-called "McJobs"-unqualified, 
poorly paid, not protected, and with no greater development perspectives (Marody \& Giza-Poleszczuk, 2004).

(6) "The corrosion of character", which results from the development of flexible capitalism, which leads to the appearance of new strains and kinds of oppressing, as well as the corrosion of those elements of human character that is responsible for the strength of interpersonal relations, and thus making a person an amoral individual. As Sennett (2006) observed, work flexibility causes its uncertainty and, at the same time, its being contradictory. This is so, as on the one hand, the worker is expected to be mobile, open to changes, and to taking risks; on the other hand, to be loyal and engaged, to trust their organisation and the goals it realises (Sennett, 2006). It is difficult to reconcile those two opposing attitudes today.

The presented changes in people's work do not comprehend all the possibilities in this matter. They are only the examples of the transformations that take place. However, the changes are increasingly faster and more difficult to predict. Their directions are similar all over the world, although their scale and pace are conditioned by the characteristic features of each society. The transformations mean, primarily, that there is the necessity to change the concept of work and profession, as the model of permanent, full-time employment has become anachronistic. The loss of employment security results in the necessity to permanently invest in one's professional development, which becomes sinusoidal character and forces one to continuously develop oneself, so as to be as attractive as possible to the prospective employer. Today, a worker is forced to create the feeling of employment security by themselves, by building their identity as the owner of a given career capital and the image of the job candidate that is desired from the labour market's perspective.

The analysis of the indicated changes which have gained terrific speed in the recent years, allows formulating the conclusion that in the work sphere there have occurred significant changes of qualitative character. From the civilisation development's point of view, they may be defined as very forward thinking and progressive. Work has become less strenuous and far safer, work relations have improved, and the pays have risen. At the same time, the traditional employment forms have been applied less frequently and the structure of work demand has changed more quickly. The essence of those global transformations is well described by the thesis formulated by Freud (2013) that one gains something owing to the development of civilisation, but loses something else at the same time. In relation to this statement, it is worth noting that the signalised phenomena increasingly often generate problems with maintaining work-private life balance of contemporary humans. This is why it seems significant to ask what may be its consequences for the individual, the society as well as for the organisation. The attempt to address this kind of question will be presented in the following part of deliberations.

\section{Towards Work-Life Imbalance}

Dispersing work's unity in time and space leads to the situation, in which the boundary among working time, place, and other spheres of human functioning has become more and more fluid (Tomaszewska-Lipiec, 2015). One may even try to formulate a thesis that the boundaries that previously divided work and personal spheres have almost been pushed back. There are many reasons for work overload. The most significant ones—as identified based on the Deloitte's (2015) "HR Trends 2015. New World of Work" report — may be

\footnotetext{
1 The author used the information contained in the "Making work easier: The Upcoming revolution" part in particular, by D. Agarwal, B. Rea, A. van Berkel, and the co-authors: J. Bourke, S. Harrington, T. Hodson, and M. A. Stallings. The report presents many examples of complicated procedures and organisational systems. For example, one bank noted that in the three preceding years, the cost of regulation consistency they had to bear tripled, amounting to \$265 million USD - partially because of the demand to submit 3,150 reports, of 80,000 pages in total. Another big production enterprise confessed that developing one of their key products needed introducing 4,000 various tasks, procedures, and processes to ensure consistency, pp. 2-11, 99-103.
} 
presented as the following compilation:

- The omnipresent technology and communication that favour the interlacing of professional activity, one's family and other spheres of private life contribute to the fact that people are always active, in the stand-by mode, permanently in contact with their work. Mobile devices grant permanent access to the work sphere-related data, and the specificity and flaws of human nature cause it that people become dependent upon these stimuli, thus keeping alive the vicious circle of constant readiness for work;

- Most companies, even the smallest ones, have customers, partners, and suppliers from all over the world. Projects, teleconferences, meetings, and e-mails - all these activities never cease, despite the time of day or night. Moreover, many people work in international teams, which function seven days a week and 24 hours a day;

- The phenomenon of information overburden of workers has become more severe: on average, an employer devotes one fourth of their working time to reading and answering e-mails; and they check their mobile phone over 150 times a day. It is worth noting that during one day people send over 100 billion e-mails, but only one out of seven of those messages is of significant meaning;

- In organisations, there dominate overly complicated procedures and business systems; a high level of complexity of organisation practices, business processes and posts, and increased administrative and regulation requirements. Workers all over the world have to face them, which consumes much time and energy. The data collected in the Deloitte's (2015) report show that 49\% of the researched workers from 106 countries found their work environment "complicated", and 25\% of them-“very complicated" (Deloitte, 2015);

- Increasingly more women enter the labour market, which equals changes in the contemporary family's model, as well as increasing overburden of professional and family duties. For example, in the USA, only $17 \%$ of households base on the traditional family form, in which the man works professionally and the woman takes care of the house. Before, there were $63 \%$ of such households (Belkin, 2006).

The presented factors, to a very large extent, influence the disturbances in the relations between work and private life, although the presented set is not a closed one. It is worth noting that although the management literature shows that the factors that motivate workers have changed, i.e. they are more often oriented towards attractive and friendly work environment, according to the National Journal's research ${ }^{2}, 40 \%$ of Americans believe it is impossible to be successful at work, earn a lot of money and, simultaneously, have enough time to devote to one's family and local community. It is thus possible to notice the increase in the tensions between professional work and private sphere, which manifests itself in imbalance and perceiving both those spheres as mutually contradictory, as well as results in negative consequences for workers and economics and society.

What does the notion of work-life balance mean, then? Generally speaking, balance, often called equilibrium or homeostasis, means a stable system of contradictory forces or values, which is characterised by the ability to self-regulate. When referring this interpretation to human's life, one may state that it means the harmonious functioning of the individual, which enables them to reconcile all the areas of their functioning. There is balance, when work does not appropriate one's extraprofessional life, and vice versa—when one's

\footnotetext{
${ }^{2}$ According to the New Allstate/National Journal survey, slightly more than half of Americans believe that it is possible to achieve balance petween and professional life. http://www.nationaljournal.com/press-room/new-allstate-national-journal-heartland-mon-itor-poll-finds-narrow-majority-of-ameri cans-see-work-life-balance-as-attainable-20141114, accessed 20.01.2015 (Source: Deloitte, Trendy HR 2015. Nowy świat pracy, Deloitte University Press, p. 100).
} 
private life is not spent on work's expense. At the level of the individual, it means the ability to combine work with other dimensions of human life - home, family, health, social activity, private hobbies, etc. (Borkowska, 2011). One can talk about balance, when work and private life begin to be well-adjusted elements of an entity, when they become allies that allow fulfilling diverse tasks, functions, and life roles. For reconciling professional and extraprofessional duties, their harmonious interlacing is necessary to regenerate one's energies and crucial for one's wellbeing and deriving satisfaction from what one does. It must be emphasised, though, that identifying the balance between those two spheres solely with the proportional division of the time devoted to them, is not entirely right and may lead to leaving out the negative consequences of disturbances in the balance between them that are also caused by other factors, such as:

- The quality of work, which means its character, security, the feeling of self-realisation, work being stressogenic, work organisation and environment, work protection, vertical and horizontal interpersonal relations, etc.;

- Work intensity and the excessive amount of tasks the individual are being given, which may lead to making mistakes and to stress, as well as to taking those tasks home;

- Strong orientation towards career;

- Confronting the amount of time spent on working and commuting, and the family duties with one's free time (Ibidem).

The challenge that most workers face nowadays is the necessity to properly share time and energies between professional duties and private life. Often, the professionally active people do not notice it early enough, that the lack of this balance disharmonises their lives and leads to role conflict. This is so, as its consequences become visible after some time. In following Table 1, there have been signalised the selected consequences of the lack of balance, perceived at the individual, organisational, and social/economic level.

Table 1

Some Negative Consequences of the Lack of Balance Between Work and Non-Work Life

\begin{tabular}{|c|c|c|}
\hline $\begin{array}{l}\text { For societies at the macro level } \\
\text { (national, regional, etc.) }\end{array}$ & For economic organizations & $\begin{array}{l}\text { For employees } \\
\text { and their families }\end{array}$ \\
\hline $\begin{array}{l}\text { - decreasing number of births, } \\
\text { - deferring the birth of the first child, } \\
\text { - growing number of divorces, } \\
\text { - growing number of single-parent families, } \\
\text { - growing social inequality, } \\
\text { - increasing incidence of heart diseases, } \\
\text { cancer and neurological diseases, } \\
\text { - insufficient childcare, } \\
\text { - growing sphere of pathology among } \\
\text { them. }\end{array}$ & $\begin{array}{l}\text { - absenteeism, } \\
\text { - fluctuation increase; loss of investment } \\
\text { in human capital, } \\
\text { - less commitment to work, } \\
\text { - stress, } \\
\text { - lower concentration at work; } \\
\text { - worse quality of work and reduced } \\
\text { productivity, } \\
\text { - worse relationships with customers and } \\
\text { frequent loss, } \\
\text { - less creativity and innovation, } \\
\text { - lower profits and worse competitive } \\
\text { position. }\end{array}$ & $\begin{array}{l}\text { - stress, } \\
\text { - conflicts in the family, } \\
\text { - worse childcare, } \\
\text { - divorces, } \\
\text { - alcoholism, } \\
\text { - falling prey to drugs, } \\
\text { - dependence on cigarettes or sweets, } \\
\text { - insecurity of work and family. }\end{array}$ \\
\hline
\end{tabular}

Source: Borkowska (2010).

Taking the contents of Table 1 into consideration, it should not be questionable to state that the activities towards work - private life balance seem justified, or even necessary. The ways of settling the role conflict may be sought at different levels. The following article signalizes the two following issues:

(1) Workers' time management skills.

(2) Strategic thinking of workers within the organization management process (Pluta, 2014, p. 188). 
The first of the aforementioned circumstances concern workers and decisions related to distributing their time among particular life activities, i.e. to the conscious using of the personal resources in the best way, which means economic and ecological way. The people, who can manage themselves, use their personal resources skilfully; they do not overexploit them in one of the spheres of their functioning and consciously pursue their professional and non-work goals, while seeking balance at the same time. It must be mentioned that people are able to time-manage themselves if they are both aware of their potential and know the principles of rational distributing activities in time. Pluta's (2014) research results showed that many workers live in the constant feeling of lack of time and disturbed balance between their work and private lives. The main reasons for such a state are, e.g.:

- Mistakes in organising one's own actions (e.g. not noting down the agendas or work plans; concentrating on work only and not taking leisure time into account when arranging the activity schedules);

- Not being able to control the so-called time thieves, that is distracting, useless activities which make the overall time of performing important tasks longer;

- Not knowing the tools that make it easier to manage time in a rational way (e.g. the SMART method, Patero's principle, Eisenhower's matrix, ABC analysis, the efficiency curve, etc.);

- No practical application of the time management instruments, despite knowing them (There is a common attitude: "I know them but I do not use them");

- Not being able to learn from one's mistakes, and from other people's mistakes (i.e. the lack of drawing conclusions from the previous work management actions leads to repeating the incorrectness and does not incline to searching for rational ways of managing time) (Pluta, 2013).

It is also worth emphasizing that shaping positive work-non-work life relations cannot be limited to workers' actions only. Organisations should also be involved in activities, the aim of which is to provide balance to employees. This is why the second issue worth considering, which is the strategic thinking of the worker in the organisation management process. Without the strategic attitude towards the personnel's matters, the organisation will not introduce any operating activities in this field. It seems that the point of view from which the management staff presents and defines organisational goals, and from which they shape the strategic foundations they wish to realize in the future, is key influence over the strategy. The analysis of the strategic decisions that the management makes lets one distinguish two contrasting attitudes concerning the perceiving of the organisation, namely, (1) a business entity, oriented towards making a profit, and (2) a social institution which concentrates on fulfilling various needs of its employees (Eisentat, Beer, Foote, Fredberg, \& Norrgren, 2008).

The aforementioned attitudes may manifest themselves, with various intensity in the organization strategy planning processes, as shown in the illustration.

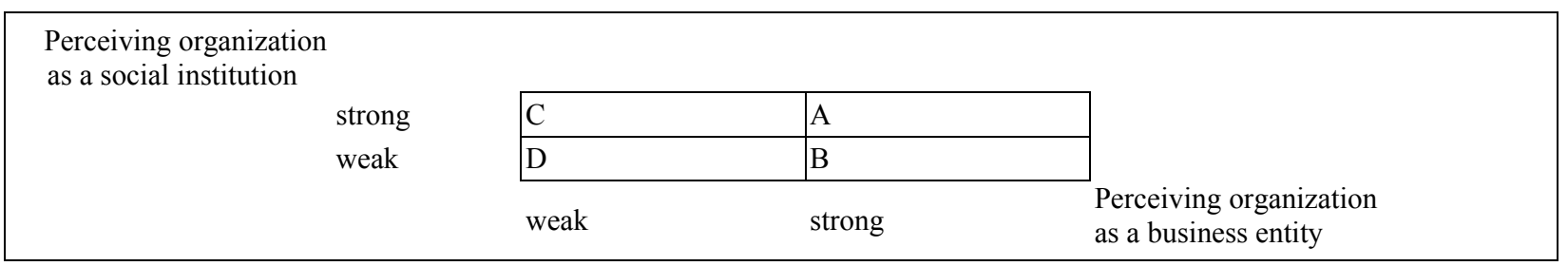

Figure 2. The types of strategic thinking that result from the ways of perceiving an organization. Source: Pluta (2014).

When interpreting Figure 2, one should take it into consideration that in some organisations there is type A strategic thinking to be observed that does not favour one way of perceiving it, but takes their two-dimensional 
nature into account - a business entity and a social institution. This means that in the process of making decisions concerning the functioning of such organisations, both the profit and the workers who make it are of key importance. The financial results are significant, but they are treated as a kind of test to the organisation's worth, raisond'être of the undertaken actions and business decisions the organisation makes. The employees may expect that they will be treated as people who have needs that are not only related to work, but which are also important in their personal lives. It seems terrifying that many contemporary organisations base their functioning on using the type B strategic thinking, i.e. the thinking that is strongly oriented towards being a business entity and does not notice the other dimension of the organisation - a social institution. Practically, this kind of approach contributes to the fact that the economic results are valued much more highly than the people who produce them. This results in treating workers and the matters that concern them as objects, which leads to overexploitation of the staff and to general lack of interest in personnel. There are also some organisations, the strategic thinking of which is of the type $\mathrm{C}$, which is strongly oriented towards satisfying various social needs like, for example, the need of employment, social security, worker's satisfaction, cultural and aesthetic needs, environmental protection, etc. Being a business entity and making profit are of secondary role, or is even beyond the focus of attention. Only non-profit organisations are able to adopt this point of view, though. The type D strategic thinking is characteristic to the organisations that are interested in being neither a business entity nor a social institution. Those are organisations of low awareness of their goals, the functioning of which is dependent on accidental, random events. This kind of behaviour leads to failure and ultimate downfall (Pluta, 2014).

To sum this part of reflections up, one may arrive at a conclusion that the type of strategic thinking the organisations applied influences the shaping of work-personal life balance of contemporary workers. It may make it easier to achieve it. It may also impede it, or even make it impossible to achieve. One must agree with it though, that the actions oriented towards supporting workers in their combining the contradicting professional and personal duties may be seen as the human resource investment, which favours increasing the competitive advantage of the organisation.

At present, more and more importance is being attached to build the image of a family- and worker-friendly enterprise. For instance, those actions may concern the following five categories:

- Taking care of children and other dependants of the worker.

- Providing flexible employment conditions.

- Making it possible to get occasional leaves if the worker is in a specific life situation.

- Providing information services concerning health, law, and culture.

- Giving workers support in non-work areas, e.g. culture, leisure, and health (Syper-Jędrzejak, 2014).

Discussing the issue of work-personal life balance encourages more reflection. The actions in this area, whether undertaken or suggested, often become the "social services" in organisations. This begs a question if those actions really aimed at striking the aforementioned balance, or maybe - at making it easier for the employees to perform better at work or be more engaged in work, by providing childcare, health care, recreation, leisure, and social support? Apparently, the answer to this question is not unambiguous.

\section{Conclusions}

The transformations in work sphere increasingly often lead to negative consequences for the personal lives of employees. When considering this issue, one must take it into consideration that it poses something of a paradox. On the one hand, it is said and written about the end of work and more leisure time, which should 
favour keeping the balance between professional and extraprofessional activities. On the other hand, one may observe an increasing dependence on work, the pressure to be constantly ready to work, open for challenges, in order to win employer's admiration. This is why, when summing the presented reflections up, one may assume that in the broader context, the "work-life balance" means thinking of one's biography as of something which is balanced, in which the individual is in the centre and that what surrounds them is only the context of their lives. In such an approach, it is important to fulfil one in all the existential dimensions. This "fulfilling one" does not have to mean one who is perfect at everything. It may mean the phenomenon of good enough, i.e. to live, to have, and to work - not in a perfect way but well enough. This principle has become a life credo of many young people (especially from generations $\mathrm{Y}$ and $\mathrm{Z}$ ). Adopting this kind of attitude will not probably gain employers' acceptance. It also will not favour the development of professional career and self-fulfilling of the workers who want it and who care much about it. However, it is worth considering whether or not it will help to maintain work-life balance.

\section{References}

Belkin, L. (2006). Life's work: Flex time for the rest of us. New York Times, December 17.

Borkowska, S. (2010). The balance between work and non-work life. Acta UniversitatisLodziensis Folia Economica, $240,17$.

Borkowska, S. (2011). Ile pracy, ile życia poza nią? In S. Borkowska (Ed.), Programy praca-życie. Z teorii i praktyki (pp. 18-20). Warszawa: IPiSS.

Castells, M. (2007). Społeczeństwo sieci. Warszawa: Wydawnictwo Naukowe PWN.

Deloitte. (2015). Trendy HR 2015. Nowy świat pracy. Deloitte University Press.

Eisentat, R. A., Beer, M., Foote, N., Fredberg, T., \& Norrgren, F. (2008). Bezkompromisowy lider. Harvard Business Review Polska, 65-66, 131-132.

Freud, Z. (2013). Kultura jako źródto cierpień. Aletheia.

Handy, C. (1998). Wiek przezwyciężonego rozumu. Warszawa: Business Press.

Marody, M., \& Giza-Poleszczuk, A. (2004). Przemiany więzi społecznych. Zarys teorii zmiany społecznej. Warszawa: Wydawnictwo Naukowe Scholar, 254.

Pluta, A. (2013). Umiejętność organizacji pracy własnej jako determinanta zapewnienia równowagi praca-życie społeczeństwa informacyjnego. Nierówności Społeczne a Wzrost Gospodarczy, 32, 285-296.

Pluta, A. (2014). Uwarunkowania kształtowania relacji praca-Życie pozazawodowe współczesnych pracowników. In R. Tomaszewska-Lipiec (Ed.), Równowaga praca-życie pozazawodowe drogq do zrównoważonego rozwoju [Work-personal life balance as the way to sustainable development] (pp. 184-189). Bydgoszcz: Uniwersytet Kazimierza Wielkiego.

Rifkin, J. (2001). Koniec pracy. Schyłek sity roboczej i poczatek ery postrynkowej. Wrocław: Wydawnictwo Dolnośląskie.

Sennett, R. (2006). Korozja charakteru. Osobiste konsekwencje pracy w nowym kapitalizmie. Warszawa: Warszawskie Wydawnictwo Literackie MUZA SA.

Standing, G. (2011). The precariat: The new dangerous class. Bloomsbury Academic.

Syper-Jędrzejak, M. (2014). Narzędzia wspierania równowagi praca-życie-Wybrane przykłady z praktyki gospodarczej. Zarzadzanie Zasobami Ludzkimi, 1, 154.

Tomaszewska-Lipiec, R. (2015). Transformations of working time as a factor of labour dehumanization. China-USA Business Review, 14(8), 417-425. 